\title{
Physicochemical properties and sensory acceptance of Canavalia ensiformis tempeh energy bar
}

\author{
${ }^{1}$ Zainal Abidin, N.A., ${ }^{1}$ Mohd Zin, Z., ${ }^{2}$ Abdullah, M.A.A. ${ }^{3,4}$ Rusli, N.D. and ${ }^{1}$ ZZainol, M.K. \\ ${ }^{1}$ Faculty of Fisheries and Food Science, Universiti Malaysia Terengganu, 21030, Kuala Nerus, Terengganu \\ ${ }^{2}$ Faculty of Science and Marine Environment, Universiti Malaysia Terengganu, 21030, Kuala Nerus, \\ Terengganu \\ ${ }^{3}$ Faculty of Agro Based Industry, Universiti Malaysia Kelantan, Jeli, Kelantan, Malaysia \\ ${ }^{4}$ Institute of Food Security and Sustainable Agriculture, Universiti Malaysia Kelantan, Jeli, Kelantan, \\ Malaysia
}

\section{Article history: \\ Received: 7 April 2020 \\ Received in revised form: 12 May 2020 \\ Accepted: 15 May 2020 \\ Available Online: 8 June 2020}

\section{Keywords:}

Canavalia ensiformis,

Tempeh energy bar,

Sensory evaluations

DOI:

https://doi.org/10.26656/fr.2017.4(5).150

\begin{abstract}
The food industry needs a creative approach to innovation in order to produce revolutionary materials, innovations and fresh, nutritious, sustainable food products. Tempeh is a traditional meal prepared using Rhizopus oligosporus to ferment dehulled and cooked soybeans to a compact and sliceable cake. Because of their high content of proteins, carbohydrates, lipids, and minerals, energy bars are snacks offering good sensory and nutritional properties. Canavalia ensiformis (Kacang Koro), is an underutilised legume that contains up to $32 \%$ of protein. To our knowledge, no prior studies have studied regarding tempeh and energy bars, especially in Malaysia. This research aimed to evaluate both the physicochemical properties and sensory acceptance of the C. ensiformis tempeh energy bar. Energy bars of six formulations (Formulation A - E) were produced using different percentages of $C$. ensiformis tempeh namely $0 \%, 4.8 \%, 9.5 \%, 14.3 \%$, $19.0 \%$ and $23.8 \%$. The physical characteristics of the energy bar were analysed based on colour profile analysis, texture analysis and also the $\mathrm{pH}$ value, while the chemical characteristics were analysed based on proximate analysis, calories, mineral content, and toxicity analysis. The results showed that the energy bars consist of moisture content of 9.29-13.09\%, ash of $0.99-1.56 \%$, crude fibre of $1.82-7.27 \%$, protein of $4.93-10.34 \%$, crude fat of 12.36-15.97\%, carbohydrate of 58.91-64.94\%, and calorie content of 4627.55 - 5267.80 cal. Energy bars with $23.8 \%$ of $C$. ensiformis tempeh exhibited highest in moisture and protein, moderate in ash and fibre and showed no significance in carbohydrate and fat contents. The taste and overall acceptability indicate that formulation A showed the best acceptance among the prepared formulations. The utilization $C$. ensiformis tempeh could diversify the usage of $C$. ensiformis in the food industry, hence promoting their application.
\end{abstract}

\section{Introduction}

Tempeh is a traditional fermented soy food, prepared from soaked and cooked soybeans by salt-free aerobic fermentation using Rhizopus oligosporus (Krisnawati and Adie, 2015). Freshly prepared tempeh is a cake-like substance that is fully coated and filled with white mycelium, with a clean, yeasty odour (Xiao, 2011). Tempeh is usually cooked before it is eaten, and preparation usually involves frying, deep-fat frying, or baking the product (Wilson, 1995). Tempeh is considered as a good source of protein, vitamins, antioxidants, phytochemicals, and other bioactive beneficial substances (Mani and Ming, 2017).

Canavalia ensiformis or Kacang Koro contain more than $32 \%$ protein, yet they also produce somewhat mild antinutrient content (protease inhibitors, lectins, saponins and tannins) in the form of anti-nutritional factors (Eke et al., 2007) which makes them not popular as human food. Therefore, few treatments have been conducted to render $C$. ensiformis edible to humans, such as heating, fermentation and extrusion, though obtaining favourable results (Tepal et al., 1994).

The concept behind energy bars is to provide anyone on the go with a quick snack or breakfast (Zhu and 
Labuza, 2010). The energy bar is a convenient and healthy ready to eat food that supplies balanced nutrients which contain protein, fat, minerals, vitamins and carbohydrates (Ho et al., 2016). Chitkara et al. (2017) reported that the primary purpose of energy bars is to satisfy hunger, replace a meal, and provide essential nutrition. The current market's energy bars are filled with a lot of fruit, nuts, granola, and sugar combinations (Norajit et al., 2011) to increase the product's sugar, protein, and fibre content. The consumers are concerned about getting healthier foods, and this has changed their eating habits which promoted growth in the energy bar market (Silva et al., 2016). Energy bar provides an effective sensory and nutritious snack because of their high carbohydrate, protein, lipid, and mineral content (Nadeem et al., 2012). Athletes and other physically active people also use energy bars to fulfil their nutritional needs, since they can have high amounts of protein, fats and carbohydrates (Norajit et al., 2011).

The protein content in energy bars was usually derived from soybeans and milk products as well as from other protein sources, such as peanut butter, nuts, to increase the protein quality (Aldrich, 2015). The development of the new product based on a "modified version' of underutilised legumes such as $C$. ensiformis could produce a better form of energy bar hence increasing the usage of these underutilized legumes. The purpose of this research was therefore to evaluate the effect of $C$. ensiformis tempeh on the physicochemical properties and the sensory acceptability of the $C$. ensiformis energy bar.

\section{Material and methods}

\subsection{Raw materials}

C. ensiformis was harvested from Kuala Berang, Terengganu. The starter tempeh was obtained from Teluk Panglima Garang, Selangor. Other ingredients used in the production of $C$. ensiformis tempeh energy bar include butter, raisins, honey, and brown sugar which were purchased in Kuala Terengganu, Terengganu, Malaysia.

\subsection{Preparation of Canavalia ensiformis tempeh}

C. ensiformis tempeh was prepared according to the procedure described by Kustyawati et al. (2017) with some modification. C. ensiformis beans were washed and soaked in clean tap water at room temperature $\left(28^{\circ} \mathrm{C}\right)$ for $48 \mathrm{hrs}$ and the soaking water was changed 5 times, and then boiled for 30 mins (the ratio of water to $C$. ensiformis was $3: 1$ ). This was followed by dehulling to remove $C$. ensiformis skin from the cotyledon manually, and another boiling for 30 mins (Wan Mohamad Din et al., 2020). Subsequently, C. ensiformis was boiled, drained and air-dried. Then, $0.02 \mathrm{~g}$ of Rhizopus mold was inoculated for every $100 \mathrm{~g}$ cooked $C$. ensiformis, and packed into plastic bags, then incubated for $36 \mathrm{hrs}$ at $32^{\circ} \mathrm{C}$. The prepared tempeh was then kept in $4^{\circ} \mathrm{C}$ prior to further usage.

\subsection{Preparation of Canavalia ensiformis tempeh energy bar}

All the ingredients were weighed based on the formulations presented in Table 1. The sliced ' $C$. ensiformis tempeh' was then roasted in the oven for $1 \mathrm{hr}$ at $100^{\circ} \mathrm{C}$. The $C$. ensiformis tempeh was then grind to small size using mortar and pestle. Prior to the mixing process, almonds were roasted for 10 mins in the oven, while oats also were baked for 10 mins. All the ingredients were cut to small sizes before mixing in a bowl. Brown sugar, honey, and butter were heated at low temperature $\left(40^{\circ} \mathrm{C}\right)$ and then mixed with roasted ingredients. The prepared mixture was then pressed to produce a rectangular shape in a mould. The energy bar was then kept in the chiller $\left(4^{\circ} \mathrm{C}\right)$ prior to further analysis (Wan Mohamad Din et al., 2020).

Table 1. The formulation and ingredients of C. ensiformis tempeh energy bar

\begin{tabular}{|c|c|c|c|c|c|c|}
\hline \multirow[b]{2}{*}{ Ingredients } & \multicolumn{6}{|c|}{ Formulation } \\
\hline & $\begin{array}{l}0 \\
\stackrel{0}{0}\end{array}$ & A & B & $\mathrm{C}$ & $\mathrm{D}$ & $\mathrm{E}$ \\
\hline Honey (g) & 15 & 15 & 15 & 15 & 15 & 15 \\
\hline Almonds (g) & 25 & 20 & 15 & 10 & 5 & 0 \\
\hline C. ensiformis tempeh (g) & 0 & 5 & 10 & 15 & 20 & 25 \\
\hline Raisin (g) & 10 & 10 & 10 & 10 & 10 & 10 \\
\hline Brown sugar (g) & 20 & 20 & 20 & 20 & 20 & 20 \\
\hline Instant oat $(\mathrm{g})$ & 10 & 10 & 10 & 10 & 10 & 10 \\
\hline Butter (g) & 15 & 15 & 15 & 15 & 15 & 15 \\
\hline Total & 105 & 105 & 105 & 105 & 105 & 105 \\
\hline
\end{tabular}

\subsection{Colour profile analysis}

The instrument that was used to measure the colour was Konica Minolta colourimeter (Konica Minolta, Tokyo, Japan) based on L*a*b* colour system, where L (lightness), a (redness) and $b$ (yellowness). The colourimeter was calibrated by using a white calibration plate before analysis. The instrument was placed on the energy bar formulation and the values of $\mathrm{L}^{*}$ (lightness), $a^{*}$ (redness) and $b^{*}$ (yellowness) for each energy bar was recorded and analysed (Zainol et al., 2020).

\subsection{Texture profile analysis}

The analysis was conducted using a TA.XT.Plus texture analyzer (Stable Microsystems, UK) to determine the hardness, and factorability of the energy bar based on 
the mechanical characteristics where material was subjected to a controlled force from a deformation curve of response. The sample was placed centrally under the 3 -point bend rig probe until the probe came to contact with the sample. Then, the deformation curves were recorded (Mamat et al., 2018).

\section{$2.6 \mathrm{pH}$ analysis}

The acidity and alkalinity of the energy bar samples were determined using a $\mathrm{pH}$ meter (Mettler Toledo, Ohio, USA). The samples (5 g) were finely mixed and homogenized with $20 \mathrm{~mL}$ of distilled water, and measured the $\mathrm{pH}$ value.

\subsection{Toxicity analysis}

\subsubsection{Determination of oxalate content}

Pulverized sample $(1 \mathrm{~g})$ was weighed into a conical flask, and added to $75 \mathrm{~mL}$ of $3 \mathrm{M}$ sulphuric acid was added and stirred with a magnetic stirrer for an hour. This was filtered and $25 \mathrm{~mL}$ aliquot of the filtrate was collected and heated to $80-90^{\circ} \mathrm{C}$. This filtrate was kept above $70^{\circ} \mathrm{C}$ at all times. Next, the hot aliquot was titrated against $0.05 \mathrm{M}$ of potassium permanganate oxide $\left(\mathrm{KMnO}_{4}\right)$ until an extremely faint pale pink colour persisted for 15-30 s (Agbaire, 2011). The oxalate content was calculated as followed: $1 \mathrm{~mL}$ of $0.05 \mathrm{M}$ of $\mathrm{KMnO}_{4}=2.2 \mathrm{mg}$ oxalate.

\subsubsection{Determination of phytic acid content}

Sample $(2 \mathrm{~g})$ was weighed into a $250 \mathrm{~mL}$ conical flask. Approximately $100 \mathrm{~mL}$ of $2 \% \mathrm{HCl}$ was used to soak the sample for $3 \mathrm{hrs}$ and then filtered through filter paper. A $25 \mathrm{~mL}$ aliquot of the filtrate was placed in a separate $250 \mathrm{~mL}$ conical flask and $5 \mathrm{~mL}$ of $0.3 \%$ ammonium thiocyanate solution was added. Approximately $53.5 \mathrm{~mL}$ of distilled water was added and this will be then titrated with standard iron (III) chloride solution which contained $1.95 \mathrm{mg}$ of iron per $\mathrm{mL}$ until a brownish yellow colour persisted for 5 min (Unuofin et al., 2017). Phytic acid was calculated as follow: Phytic acid $(\%)=$ Titre value $\times 0.00195 \times 1.19 \times 100$.

\subsubsection{Determination of tannins content}

Tannin content was determined using the FolinCiocalteu method. One millilitre of energy bar sample was mixed with $7.5 \mathrm{~mL}$ of distilled water and $0.5 \mathrm{~mL}$ of Folin-Ciocalteu phenol reagent. Then, $1 \mathrm{~mL}$ of $35 \%$ sodium carbonate solution was added to the mixture and diluted to $10 \mathrm{~mL}$ with distilled water. The mixture was vigorously shaken and let it stand for $30 \mathrm{~min}$ at room temperature $\left(25^{\circ} \mathrm{C}\right)$. Absorbance for test and standard solutions were measured against blank at $725 \mathrm{~nm}$ with a UV/Visible spectrophotometer. The tannin content was expressed in terms of $\mathrm{mg}$ of $\mathrm{GAE} / \mathrm{L}$ of extract (Wan Mohamad Din et al., 2020).

\subsection{Proximate analysis}

The moisture, ash, fat, fibre and crude protein content of the $C$. ensiformis tempeh energy bar were determined according to AOAC International (2007) standard procedures. All analyses were carried out in triplicates.

\subsection{Calorie content analysis}

The calorie content was determined using a bomb calorimeter (LECO, USA). The sample was placed in the crucible in the combustion chamber for the combustion process. Once the sample is ignited, a thermometer which is partially submerged in the water records the temperature changes that occur. The heat of combustion (cal/g), the change in temperature was recorded as the calories content of the sample. (Wan Mohamad Din et al., 2020).

\subsection{Mineral content analysis}

The determination of mineral nutrient was carried out using an Inductively Coupled-Plasma-Mass Spectrophotometry (ICP-MS) (Agilent Technologies, U.S.A). Dried sample ( $2 \mathrm{~g}$ ) was placed into the crucible, burned in a furnace at $500^{\circ} \mathrm{C}$ for $24 \mathrm{hrs}$. The crucible was then cooled at room temperature and $2 \mathrm{~mL}$ of concentrated $\mathrm{HCl}$ was added and was let to evaporate to dryness on a hot plate. Then, $10 \mathrm{~mL}$ of $20 \% \mathrm{HNO}_{3}$ was added and the crucible then placed in the water bath for 1 hr. Finally, the solution was analysed using ICP-Mass Spectrophotometer.

\subsection{Sensory analysis}

The sensory evaluation session was performed based on a 7-point hedonic scale (higher score indicates better quality attributes (1, dislike very much and 7 , like very much)) (Mamat et al., 2018). The colour, aroma, appearance, crispiness and flavour of the energy bars were evaluated. All the attributes were independently judged by forty untrained panels based on their likeness. The sample was packed and coded with a 3-digit code. The mean score for each attribute was reported.

\subsection{Statistical analysis}

All data were analysed statistically using SPSS (Version 20) statistical software package. The results were expressed as mean \pm standard deviation. The significant difference at $(p<0.05)$ was performed by oneway analysis of variance (ANOVA) and Fisher's Least Significant Difference (LSD) test (Hau et al., 2018). 


\section{Results and discussion}

\subsection{Colour profile analysis}

Table 2 reveals that the $\mathrm{L}^{*}$ value of the formulations was also increased with the increasing amount of $C$. ensiformis tempeh, suggesting the influence of tempeh on the lightness of the energy bar of colour. The findings also showed that formulation A had the highest a* rating, which shows the energy bar's redness. Formulation E, on the other hand, has the lowest value of $a^{*}$ (2.67). The energy bar's red colour may be attributed to the amounts of almond in the formulation as well as the presence of other almond ingredients. The formulation D's $b^{*}$ value (yellowness) was found to be the highest (25.23), while formulation A was found to be the lowest (20.62). For the other tests, the $b^{*}$ value was identical, suggesting that the butter mixture might be other ingredients that could have led to an increased value in yellowness of energy bar. The energy bar colours are quite similar to each formulation due to the colour of its ingredients, while the amount of $C$. ensiformis tempeh and the amount of almonds gives a small effect to the bars.

\subsection{Texture profile analysis}

Table 2 shows that the hardness of the $C$. ensiformis energy bar (formulation D) was found to be significantly the highest $(7.71 \pm 0.37 \mathrm{~N})$ while the control formulation had the lowest hardness value $(6.44 \pm 0.73 \mathrm{~N})$. In general, the low hardness of the formulation was observed when a low amount of tempeh was incorporated into the formulation. This could mean that when the proteins are used, the bar may have a better or worse texture than expected (Imtiaz et al., 2012). In addition, all formulation s showed a somewhat similar fracturability value indicating that the tempeh did not have an analytical effect on the texture profile value. However, due to the low amount of tempeh incorporated in the formulations, low fracturability was observed in the analysis. When proteins are blended together, they may have synergistic or antagonistic effects. Moisture migration, phase separation (Hogan et al., 2012) and fat oxidation could be the main reason for the texture value recorded in this study (Dan and Labuza, 2010). Mridula et al. (2013) stated that the hardness of the energy bar is significantly affected by the level of sweeteners and flaxseed.

\section{$3.3 \mathrm{pH}$ value Analysis}

Table 3 shows the $\mathrm{pH}$ value of $C$. ensiformis tempeh energy bar ranges between 5.30 to 4.82 and the control energy bar was 5.44. The data reveal that the acidity of all formulation of energy bar was significantly different $(p<0.05)$ between control, formulation A, B and C except for formulation D and E. Control sample, illustrated the highest $\mathrm{pH}$ value compared to other formulations (5.44 \pm 0.01$)$, while formulation $\mathrm{E}$ exhibited the lowest $\mathrm{pH}$ value (4.82). According to Silva et al. (2016), the $\mathrm{pH}$ value of the energy bar incorporated with jeriva flour ranged from 6.78 to 6.92 , where the $\mathrm{pH}$ of jeriva flour itself is 4.96. Compared to $C$. ensiformis tempeh energy bar, the $\mathrm{pH}$ value obtained was acidic. The ingredient that probably caused the $\mathrm{pH}$ above 5 is honey. This could be because the average $\mathrm{pH}$ of honey is 3.9, with a typical range of 3.4 to 6.1 (White et al., 1962).

\subsection{Toxicity analysis}

\subsubsection{Oxalate content}

Table 3 shows the oxalate content of $C$. ensiformis tempeh energy bar formulation and control. The results showed that there was a significant difference $(p<0.05)$ between formulation $\mathrm{D}$ and $\mathrm{E}$ except for formulation control A, B and $\mathrm{C}$ which showed no significant difference. The range of oxalate content of $C$. ensiformis tempeh energy bar was from $45.43 \mathrm{mg}$ to $54.90 \mathrm{mg}$ while the formulation control was $45.10 \mathrm{mg}$. The formulation $\mathrm{E}$ has the highest oxalate content which was $59.4 \mathrm{mg}$, meanwhile formulation A has the lowest which was $45.43 \mathrm{mg}$. Such a finding could be explained by the increasing amount of $C$. ensiformis tempeh in the energy bar which increased in the oxalate content. Fermentation also caused the changes of some organic acids such as acetic acid, oxalic acid, citric acid and succinic acid, which eventually influenced the $\mathrm{pH}$. This finding was in agreement with previous studies on soybean fermentation using $R$. oligosporus starter (Vong et al., 2018) or Rhizopus starter (Moa et al., 2013). A possible explanation for these results may be the fermentation of C. ensiformis helps to reduce the amount of oxalate in the legume. Besides, fermentation helps to reduce the

Table 2. The colour profile analysis for $\left(\mathrm{L}^{*} \mathrm{a}^{*} \mathrm{~b}^{*}\right)$, hardness and fracturability of the C. ensiformis tempeh energy bars

\begin{tabular}{cccccc}
\hline Formulation & $\mathrm{L}^{*}$ & $\mathrm{a}^{*}$ & $\mathrm{~b}^{*}$ & Hardness $(\mathrm{N})$ & Fracturability $(\mathrm{mm})$ \\
\hline Control & $49.42 \pm 1.05^{\mathrm{bc}}$ & $5.33 \pm 0.41^{\mathrm{a}}$ & $24.18 \pm 0.24^{\mathrm{ab}}$ & $6.44 \pm 1.73^{\mathrm{b}}$ & $44.66 \pm 1.49^{\mathrm{b}}$ \\
A & $47.52 \pm 4.00^{\mathrm{c}}$ & $5.37 \pm 0.39^{\mathrm{a}}$ & $20.62 \pm 4.06^{\mathrm{a}}$ & $6.50 \pm 0.94^{\mathrm{b}}$ & $45.80 \pm 0.27^{\mathrm{ab}}$ \\
B & $50.70 \pm 3.20^{\mathrm{bc}}$ & $4.75 \pm 0.16^{\mathrm{ab}}$ & $24.52 \pm 1.99^{\mathrm{ab}}$ & $6.55 \pm 0.78^{\mathrm{b}}$ & $45.28 \pm 0.73^{\mathrm{ab}}$ \\
C & $52.94 \pm 0.43^{\mathrm{ab}}$ & $4.53 \pm 0.16^{\mathrm{b}}$ & $25.18 \pm 1.00^{\mathrm{a}}$ & $6.83 \pm 0.99^{\mathrm{b}}$ & $46.82 \pm 0.65^{\mathrm{a}}$ \\
D & $55.44 \pm 1.15^{\mathrm{a}}$ & $3.45 \pm 0.67^{\mathrm{c}}$ & $25.23 \pm 1.28^{\mathrm{a}}$ & $7.71 \pm 0.37^{\mathrm{a}}$ & $45.14 \pm 1.06^{\mathrm{ab}}$ \\
E & $52.22 \pm 4.79^{\mathrm{bc}}$ & $2.67 \pm 0.58^{\mathrm{c}}$ & $21.38 \pm 2.37^{\mathrm{ab}}$ & $7.47 \pm 0.01^{\mathrm{ab}}$ & $44.96 \pm 0.03^{\mathrm{ab}}$ \\
\hline
\end{tabular}

Mean \pm standard deviation values with different superscript within the column are significant different at $\mathrm{p}<0.05$ 
Table 3. The $\mathrm{pH}$ values and anti-nutrients content in different formulation of $\mathrm{C}$. ensiformis tempeh energy bars

\begin{tabular}{ccccc}
\hline Formulations & $\mathrm{pH}$ & Oxalate $(\mathrm{mg})$ & Tanins $(\%)$ & Phytic Acid (\%) \\
\hline Control & $5.44 \pm 0.02^{\mathrm{a}}$ & $45.10 \pm 0.45^{\mathrm{d}}$ & $0.01 \pm 0.001^{\mathrm{d}}$ & $1.93 \pm 0.10^{\mathrm{b}}$ \\
A & $5.30 \pm 0.07^{\mathrm{b}}$ & $45.43 \pm 0.25^{\mathrm{d}}$ & $0.01 \pm 0.001^{\mathrm{d}}$ & $2.50 \pm 0.05^{\mathrm{a}}$ \\
B & $5.22 \pm 0.06^{\mathrm{c}}$ & $45.75 \pm 0.29^{\mathrm{cd}}$ & $0.001 \pm 0.0001^{\mathrm{e}}$ & $2.37 \pm 0.12^{\mathrm{a}}$ \\
C & $4.85 \pm 0.07^{\mathrm{d}}$ & $48.73 \pm 0.42^{\mathrm{c}}$ & $0.02 \pm 0.001^{\mathrm{c}}$ & $2.00 \pm 0.15^{\mathrm{b}}$ \\
D & $4.93 \pm 0.09^{\mathrm{e}}$ & $54.66 \pm 0.32^{\mathrm{b}}$ & $0.02 \pm 0.001^{\mathrm{b}}$ & $1.53 \pm 0.13^{\mathrm{c}}$ \\
E & $4.832 \pm 0.09^{\mathrm{e}}$ & $59.41 \pm 0.38^{\mathrm{a}}$ & $0.03 \pm 0.001^{\mathrm{a}}$ & $1.17 \pm 0.07^{\mathrm{d}}$ \\
\hline
\end{tabular}

Mean \pm standard deviation values with different superscript within the column are significant different at $\mathrm{p}<0.05$

anti-nutritional and toxic factors in the raw materials by making the proteins and minerals which are complex with these phytochemicals readily available (Adegbehingbe, 2015).

\subsubsection{Phytic acid content}

The results showed that there was a significant difference $(p>0.05)$ between formulation except for formulation control and $\mathrm{C}$ which has no significant difference similar to formulation $\mathrm{A}$ and $\mathrm{B}$ which also showed no significant difference (Table 3 ). The range of phytic acid content $C$. ensiformis tempeh energy bar was from $2.50 \%$ to $1.17 \%$ while the formulation control was $1.93 \%$. The formulation A contained the highest tannin level which was $2.50 \%$, meanwhile formulation $\mathrm{E}$ contained the lowest which was $1.17 \%$. This may be due to the fact that the increased percentage of $C$. ensiformis tempeh in the energy bar reduced the amount of phytic acid content in the energy bar (Sridhar and Seena, 2006).

\subsubsection{Determination of tannins content}

Table 3 shows that there was a significant difference $(p<0.05)$ between all formulations except for control and formulation A. Formulation $\mathrm{E}$ has the highest tannins content $(0.03 \%)$, while formulation $\mathrm{C}$ has the lowest $(0.00 \%)$. The highest content of tannins in formulation $\mathrm{E}$ still considers a safe percentage of tannins to be consumed. This is because high dietary levels (approximately 5\%) can cause death (Sridhar and Seena, 2006). The level of content of tannins in the $C$. ensiformis tempeh energy bar is, however, below consumable level and can still be eaten.

\subsection{Chemical composition of Canavalia ensiformis tempeh energy bar}

Table 4 indicates the moisture content of the energy bar $C$. ensiformis tempeh varying from $9.37 \%$ to $13.09 \%$ where the maximum moisture content was $13.09 \%$ and the lowest moisture content of the energy bar $C$. ensiformis tempeh was $9.37 \%$, with just $9.29 \%$ moisture content in the control energy bar. Increasing the amount of $C$. ensiformis in the formulation thereafter increases the amount of moisture content in the energy bar of $C$. ensiformis. Similar findings were reported by Arbaje et al. (2016), who stated that granola bars moisture content was affected by the amount of granola in the formulations. The highest ash content of $C$. ensiformis tempeh energy bar was recorded in formulation $\mathrm{A}$ $(1.48 \%)$ while the lowest percentage of ash content was found in the control sample. This shows that the addition of $C$. ensiformis tempeh in the formulation reduced the ash content in $C$. ensiformis tempeh energy bar. This may be due to the usage of the nuts, where the almonds itself contains higher ash content, which was $3.13 \%$ (National Germplasm Resources Laboratory, 2009). The ash content in this study could be traced to the nuts used, which could be considered as origin when minerals, such as calcium, iron and magnesium, are used (Fernandes et al., 2010).

The highest protein content was found in formula $\mathrm{E}$ $(10.34 \%)$, while the lowest protein content was found in formula B (4.93\%). There was no significant difference between formulations A, C and D (5.34\%), (5.25\%) and (5.95), respectively. The higher value of protein content

Table 4. The chemical composition of $C$. ensiformis tempeh energy bar was analysed in term of moisture, ash, protein, crude fat, crude fibre and carbohydrate.

\begin{tabular}{lcccccc}
\hline \multicolumn{1}{c}{$(\%)$} & Control & $\mathrm{A}$ & $\mathrm{B}$ & $\mathrm{C}$ & $\mathrm{D}$ & $\mathrm{E}$ \\
\hline Moisture & $9.29 \pm 0.24^{\mathrm{c}}$ & $9.37 \pm 0.22^{\mathrm{c}}$ & $9.50 \pm 0.01^{\mathrm{c}}$ & $11.83 \pm 0.64^{\mathrm{b}}$ & $12.07 \pm 0.02^{\mathrm{b}}$ & $13.09 \pm 0.29^{\mathrm{a}}$ \\
Ash & $1.56 \pm 0.03^{\mathrm{a}}$ & $1.48 \pm 0.19^{\mathrm{ab}}$ & $1.36 \pm 0.03^{\mathrm{b}}$ & $1.29 \pm 0.01^{\mathrm{b}}$ & $0.99 \pm 0.02^{\mathrm{c}}$ & $1.00 \pm 0.01^{\mathrm{c}}$ \\
Fat & $15.03 \pm 0.65^{\mathrm{a}}$ & $12.64 \pm 0.08^{\mathrm{a}}$ & $15.9 \pm 5.88^{\mathrm{a}}$ & $12.36 \pm 1.70^{\mathrm{a}}$ & $13.41 \pm 0.26^{\mathrm{a}}$ & $12.63 \pm 0.6^{\mathrm{a}}$ \\
Protein & $6.26 \pm 0.69^{\mathrm{b}}$ & $5.34 \pm 0.88^{\mathrm{bc}}$ & $4.93 \pm 0.03^{\mathrm{c}}$ & $5.25 \pm 0.22^{\mathrm{bc}}$ & $5.95 \pm 0.33^{\mathrm{bc}}$ & $10.34 \pm 0.10^{\mathrm{a}}$ \\
Fibre & $7.27 \pm 2.78^{\mathrm{a}}$ & $7.60 \pm 1.76^{\mathrm{a}}$ & $9.33 \pm 1.27^{\mathrm{a}}$ & $6.90 \pm 2.39^{\mathrm{ab}}$ & $2.65^{\mathrm{bc}} \pm 0.12$ & $1.82 \pm 0.00^{\mathrm{c}}$ \\
Carbohydrates & $60.59 \pm 2.6^{\mathrm{a}}$ & $63.58 \pm 2.32^{\mathrm{a}}$ & $58.91 \pm 7.14^{\mathrm{a}}$ & $62.37 \pm 3.65^{\mathrm{a}}$ & $64.94 \pm 0.46^{\mathrm{a}}$ & $61.12 \pm 0.84^{\mathrm{a}}$ \\
\hline
\end{tabular}

Mean \pm standard deviation values with different superscript within the row are significant different at $\mathrm{p}<0.05$ 
in energy bars may be due to the utilization of $C$. ensiformis tempeh in the energy bar production which contains higher protein compared to almonds, which was $34.47 \%$ and $21.06 \%$ respectively (Nimenibo-Uadia, 2017).

Table 4 also depicts that there was no significant difference $(p>0.05)$ in the fibre content between the sample tested. The crude fibre in $C$. ensiformis recorded in this study was higher than that of soybean $(4.28 \%)$ and kidney beans (4.2\%) (Apata and Ologhobo, 1994). The observed increase in crude fibre could be attributed to the presence of tempeh of $C$. ensiformis which provides more fibre than the $C$. ensiformis itself. The results also showed that there was no significant difference $(\mathrm{P}>0.05)$ in carbohydrate content between all formulations. The range of $C$. ensiformis tempeh energy bar was from $58.91 \%$ to $64.94 \%$, while the carbohydrate content of control energy bar formulation was $60.59 \%$. The carbohydrate source might be from the usage of brown sugar and honey in the production of $C$. ensiformis tempeh energy bars (E'zzati, 2019).

\subsection{Calorie content analysis}

Table 5 shows that there was a significant difference in the total caloric value between all formulations. The total calorie content of the energy bars ranged from 4742.5 cal to 5267.80 cal. Control sample contained significantly the highest calorie content $(5276.80 \mathrm{cal})$ while formulation $\mathrm{E}$ exhibited the lowest calorie value $(4627.55 \mathrm{cal})$. The decreasing trend of calorie value of the energy bar could be due to the reduced amount of cereals and nuts used in the bars (Okoye and EkeEjiofor, 2018).

\subsection{Mineral content analysis}

Table 5 also shows the mineral content that presents in five formulations of $C$. ensiformis tempeh energy bars and control. The data showed that Iron (Fe), Magnesium $(\mathrm{Mg})$, Calcium $(\mathrm{Ca})$, Phosphorus $(\mathrm{P})$, and Potassium $(\mathrm{K})$. Mineral level range in $C$. ensiformis tempeh energy bar was $25.32-58.63 \mathrm{mg} / \mathrm{kg}$ for potassium, $9.26-13.89$ $\mathrm{mg} / \mathrm{kg}$ for calcium, $35.55-83.44 \mathrm{mg} / \mathrm{kg}$ and $8.91-$ $18.24 \mathrm{mg} / \mathrm{kg}$ of magnesium. The iron level shows quite similar between each formulation which was in the range $1.00-2.82 \mathrm{mg} / \mathrm{kg}$ in $10 \mathrm{~mL}$ solution of sample. This shows that iron levels are not affected by an increasing amount of $C$. ensiformis tempeh and a decreasing amount of almonds. The mineral content in the energy bars was typically lowered as the amount of $C$. ensiformis tempeh increased. This result is in line with the study by Ho et al. (2016), which stated that ash content of energy snack bars is reduced when glutinous rice content increases banana puree as the main ingredient.

\subsection{Sensory analysis}

Table 6 showed that there was some variation yet no significant difference $(p>0.05)$ between all formulations. The highest value of sensory colour acceptance was formulation B and the lowest colour acceptance was exhibited in formulation E. This might be due to the ingredients such as the amount of brown sugar, almond and butter that provide colour to the energy bar used in the same amount. According to Khouryieh and Aramouni (2012), changes in flaxseed bar colour may be associated with the possibility of browning Maillard reactions between flaxseed protein and other ingredients such as honey and brown sugar. Ho et al. (2016) demonstrated that the bright brown colour of the energy snack bar may be attributed to caramelisation occurring with the presence of sugar during heating and boiling.

Formulation B exhibited the highest value for odour acceptance while the lowest was found in formulation E. The caramelization process that occurs on brown sugar may difficult the panel to distinguish the odour unless the smell of the $C$. ensiformis tempeh was strong. Ho et al. (2016) stated that the strong odour of the "energy" snack bar might be attributed by the caramelization that occurred during the heating and boiling process with the presence of sugar. Formulation A showed to the best hardness liked by the untrained panellist with a value of 5.30. Meanwhile, formulation $\mathrm{E}$ was not favoured by the panellist. Brahim et al. (2017) reported that the range of hardness for flaxseed energy bar was from $30 \mathrm{~N}$ to $40 \mathrm{~N}$. Compared to $C$. ensiformis tempeh energy bar, the hardness for formulation A was not in the range. This

Table 5. Calories, mineral content of the different formulations of $C$. ensiformis tempeh energy bar

\begin{tabular}{ccccccc}
\hline Formulations & Calorie content $(\mathrm{Cal})$ & $\mathrm{Fe}$ & $\mathrm{Ca}$ & $\mathrm{P}$ & $\mathrm{K}$ & $\mathrm{Mg}$ \\
\hline Control & $5267.80 \pm 19.09^{\mathrm{a}}$ & $1.15 \pm 0.04^{\mathrm{c}}$ & $13.89 \pm 0.35^{\mathrm{a}}$ & $61.38 \pm 0.56^{\mathrm{b}}$ & $58.63 \pm 0.18^{\mathrm{a}}$ & $18.24 \pm 0.45^{\mathrm{a}}$ \\
$\mathrm{A}$ & $5058.30 \pm 114.2^{\mathrm{b}}$ & $2.45 \pm 0.09^{\mathrm{b}}$ & $10.57 \pm 0.52^{\mathrm{bc}}$ & $83.44 \pm 3.12^{\mathrm{a}}$ & $48.63 \pm 0.44^{\mathrm{b}}$ & $13.83 \pm 0.28^{\mathrm{b}}$ \\
$\mathrm{B}$ & $4985.95 \pm 82.8^{\mathrm{b}}$ & $1.00 \pm 0.03^{\mathrm{d}}$ & $10.30 \pm 0.20^{\mathrm{c}}$ & $46.76 \pm 0.08^{\mathrm{c}}$ & $49.07 \pm 0.22^{\mathrm{b}}$ & $11.39 \pm 0.08^{\mathrm{c}}$ \\
$\mathrm{C}$ & $5002.55 \pm 73.1^{\mathrm{b}}$ & $1.12 \pm 0.04^{\mathrm{c}}$ & $9.26 \pm 0.24^{\mathrm{d}}$ & $42.33 \pm 0.56^{\mathrm{d}}$ & $41.86 \pm 0.59^{\mathrm{c}}$ & $11.54 \pm 0.30^{\mathrm{c}}$ \\
$\mathrm{D}$ & $4742.5 \pm 48.79^{\mathrm{c}}$ & $2.82 \pm 0.02^{\mathrm{a}}$ & $11.10 \pm 0.51^{\mathrm{b}}$ & $83.16 \pm 0.14^{\mathrm{a}}$ & $33.46 \pm 0.11^{\mathrm{d}}$ & $13.92 \pm 0.14^{\mathrm{b}}$ \\
E & $4627.55 \pm 75.7^{\mathrm{c}}$ & $1.10 \pm 0.04^{\mathrm{c}}$ & $9.32 \pm 0.08^{\mathrm{d}}$ & $35.55 \pm 0.35^{\mathrm{e}}$ & $25.32 \pm 0.19^{\mathrm{e}}$ & $8.91 \pm 0.11^{\mathrm{d}}$ \\
\hline
\end{tabular}

Mean \pm standard deviation values with different superscript within the column are significant different at $\mathrm{p}<0.05$ 
Table 6. Sensory analysis of the different formulations of C. ensiformis tempeh energy bar

\begin{tabular}{ccccccc}
\hline Formulations & Colour & Odour & Hardness & Fracturability & Flavour & Overall acceptance \\
\hline Control & $5.70 \pm 0.04^{\mathrm{a}}$ & $5.60 \pm 0.45^{\mathrm{a}}$ & $5.35 \pm 0.36^{\mathrm{a}}$ & $5.38 \pm 0.14^{\mathrm{a}}$ & $5.85 \pm 0.41^{\mathrm{a}}$ & $5.83 \pm 0.35^{\mathrm{a}}$ \\
A & $5.55 \pm 0.09^{\mathrm{ab}}$ & $5.45 \pm 0.25^{\mathrm{a}}$ & $5.30 \pm 0.18^{\mathrm{a}}$ & $5.28 \pm 0.42^{\mathrm{a}}$ & $5.68 \pm 0.16^{\mathrm{ab}}$ & $5.48 \pm 0.33^{\mathrm{a}}$ \\
B & $5.58 \pm 0.03^{\mathrm{ab}}$ & $5.48 \pm 0.29^{\mathrm{a}}$ & $5.18 \pm 0.38^{\mathrm{a}}$ & $5.03 \pm 0.22^{\mathrm{ab}}$ & $5.55 \pm 0.33^{\mathrm{ab}}$ & $5.48 \pm 0.23^{\mathrm{a}}$ \\
C & $5.00 \pm 0.04^{\mathrm{c}}$ & $5.15 \pm 0.42^{\mathrm{ab}}$ & $4.40 \pm 0.26^{\mathrm{b}}$ & $4.38 \pm 0.35^{\mathrm{bc}}$ & $5.13 \pm 0.23^{\mathrm{bc}}$ & $4.83 \pm 0.17^{\mathrm{b}}$ \\
D & $5.15 \pm 0.02^{\mathrm{bc}}$ & $4.73 \pm 0.32^{\mathrm{bc}}$ & $4.28 \pm 0.19^{\mathrm{b}}$ & $4.48 \pm 0.23^{\mathrm{c}}$ & $4.78 \pm 0.34^{\mathrm{c}}$ & $4.58 \pm 0.24^{\mathrm{b}}$ \\
E & $4.83 \pm 0.04^{\mathrm{c}}$ & $4.20 \pm 0.38^{\mathrm{c}}$ & $3.90 \pm 0.32^{\mathrm{b}}$ & $3.98 \pm 0.09^{\mathrm{c}}$ & $3.65 \pm 0.14^{\mathrm{d}}$ & $4.05 \pm 0.22^{\mathrm{c}}$ \\
\hline
\end{tabular}

Mean \pm standard deviation values with different superscript within the column are significant different at $\mathrm{p}<0.05$

study also showed that the degree of likeness for $C$. ensiformis tempeh energy bar decreased as the hardness decreased.

The results also showed no significant difference $(p<0.05)$ in flavour acceptance between all samples except formulation E. The results was affected by the different amount of $C$. ensiformis tempeh incorporated in the product. However, formulation A showed the best formulation of $C$. ensiformis tempeh energy bar liked by the panellists while formulation $\mathrm{E}$ was the least.

The colour, odour, hardness, fracturability and taste, the panellist selected the most agreed formulation A compared to other formulations. This might be due to the different percentage of $C$. ensiformis in the formulation that affected the characteristics of the energy bar.

\section{Conclusion}

This study exhibited that $C$. enformis tempeh may serve as an excellent candidate for the development of an alternative energy bar using rich protein raw materials which have been under exploited. Formulation A was mostly accepted by the panellist. This product is safe to be consumed as the level of the toxicity is still within a safe range. This study shows that $C$. ensiformis tempeh can be used in energy bar production, thereby encouraging its use in the food industry.

\section{Conflict of interest}

The authors declare that there is no conflict of interest.

\section{Acknowledgement}

The authors are grateful to the Faculty of Fisheries and Food Sciences, and the Centre of Research and Field Services Lab for providing basic facilities and resources for this work as well as CW Agro Sdn. Bhd. for providing the Jack Beans.

\section{References}

Adegbehingbe, K.T. (2015). Effect of starter cultures on the anti-nutrient contents, minerals and viscosity of
Ogwo, a fermented sorghum-Irish potato gruel. International Food Research Journal, 22(3), 12471252.

Agbaire, P.O. (2011). Nutritional and anti-nutritional levels of some local vegetables (Vernomia anydalira, Manihot esculenta, Telfairia occidentalis, Talinum triangulare, Amaranthus spinosus) from Delta state, Nigeria. Journal of Applied Science Environmental Management, 15(4), 625-628.

Aldrich, M. (2015). Inside an energy bar. https:// experiencelife.com/article/inside-an-energy-bar/

AOAC International. (2007). Official Methods of Analysis of AOAC International. AOAC Official Method 990.26. 17th ed. Gaithersburg, MD. USA: AOAC International.

Apata, D.F. and Ologbo, A.D. (1994). Biochemical evaluation of some Nigerian legume seeds. Food Chemistry, 49(4), 333-338. https:// doi.org/10.1016/0308-8146(94)90001-9

Arbaje, R., Hassan, C.Z., Noelelawati, A., Abdul Rahman, A. and Huda-Faujan, N. (2016). Development and physico-chemical analysis of granola formulated with puffed glutinous rice and selected dried Sunnah foods. International Food Research Journal, 23(2), 498-506.

Brahim, B., Thiry, J.F., Nadia, R. and Christophe, B. (2017). Effect of pear apple and date fibres incorporated on the physico-chemical, sensory and nutritional characteristics and the acceptability of cereals bars. Article of Food Science and Technology International, 24(3), 198-208. https:// doi.org/10.1177/1082013217742752

Chitkara, M., Kohli, R., Sandhu, I.S. and Singh, D. (2017). Development and nutritional, organoleptic, biochemical analysis of polyherbal (stevia, banana, cocoa butter, oats) energy bar. Journal of Advances in Food Science and Technology, 4(2), 62-66.

Dan, Z. and Labuza, T.P. (2010). Effect of cysteine on lowering protein aggregation and subsequent hardening of whey protein isolate (WPI) protein bars in WPI/buffer model systems. Journal of Agricultural and Food Chemistry, 58(13), 79707979. https://doi.org/10.1021/jf100743z 
Eke, C.N.U., Asoegwu, S.N. and Nwandikom, G.I. (2007). Some physical properties of Jackbean seed (Canavalia ensiformis). Agricultural Engineering International: The CIGR Ejournal Manuscript, 9, 111.

E'zzati，H.N. (2019). Physicochemical properties and sensory attributes of 'Kacang Koro' and almond energy bar affected by incorporation of different percentages of arabic gum and honey. Terengganu, Malaysia: Universiti Malaysia Terengganu, BSc. Thesis.

Fernandes, F., Lourenco, P. and Castro, F. (2010). Ancient clay bricks: Manufacture and properties. In Bostenaru, D.M., Poikryl, R. and Torok, A. (Eds.) Materials, technologies and practice in historic heritage structures, p. 29-48. Netherlands: Springer. https://doi.org/10.1007/978-90-481-2684-2_3

Hau, E.H., Mohd Zin, Z., Nasution, Z., Shaharudin, N.A. and Zainol, M.K. (2018). Physicochemical properties of powdered protein hydrolysate from Yellowstripe scad (Selaroides leptolepis) fish. International Food Research Journal, 25(6), 2555-2561.

Ho, L.H., Tang, J.Y.H., Mazaitul Akma, S., Mohd Aiman, H. and Roslan, A. (2016). Development of novel "energy" snack bar by utilizing local Malaysian ingredients. International Food Research Journal, 23(5), 2280-2285.

Hogan, S.A., Chaurin, V., O'Kennedy, B.T. and Kelly, P.M (2012). Influence of dairy proteins on textural changes in high-protein bars. International Dairy Journal, 26(1), 58-65. https://doi.org/10.1016/ j.idairyj.2012.02.006

Imtiaz, S.R., Kuhn-Sherlock, B. and Campbell, M. (2012). Effect of dairy protein blends on texture of high protein bars. Journal of Texture Studies, 43(4), 275-286. https://doi.org/10.1111/j.17454603.2011.00337.x.

Khouryieh, H. and Aramouni, F. (2012). Physical and sensory characteristics of cookies prepared with flaxseed flour. Journal of the Science of Food and Agriculture, 92(11), 2366-2372. https:// doi.org/10.1002/jsfa.5642.

Krisnawati, A. and Adie, M.M. (2015). Selection of soybean genotypes by seed size and its prospects for industrial raw material in Indonesia. Procedia Food Science, 3, 355-363. https://doi.org/10.1016/ j.profoo.2015.01.039

Kustyawati, M.E., Nawansih, O. and Nurdjanah, S. (2017). Profile of aroma compounds and acceptability of modified tempeh. International Food Research Journal, 24(2), 734-740.

Mamat, H., Akanda, J.M.H., Zainol, M.K. and Yu, A.I.
(2018). The influence of seaweed composite flour on the physicochemical properties of muffin. Journal of Aquatic Food Product Technology, 27(5), 635-642, https://doi.org/10.1080/10498850.2018.1468841

Mani, V. and Ming, L.C. (2017). Tempeh and other fermented soybean products rich in isoflavones. In Fermented Foods in Health and Disease Prevention. In Frías, J. and Martínez-Villaluenga, C. (Eds). Fermented Foods in Health and Disease Prevention, p. 453-473. USA: Academic Press. https:// doi.org/10.1016/B978-0-12-802309-9.00019-4

Moa, H., Kariluoto, S., Piironen, V., Zhu, Y., Sanders, M.G., Vincken, J.P., Wolkers-Rooijackers, J. and Nout, M.J.R. (2013). Effect of soybean processing on content and bioaccessibility of folate, vitamin B12 and isoflavones in tofu and tempe. Food Chemistry, 141(3), 2418-2425. https:// doi.org/10.1016/j.foodchem.2013.05.017

Mridula, D., Singh, K.K. and Barnwal, P. (2013). Development of omega-3 rich energy bar with flaxseed. Journal of Food Science and Technology, 50(5), 950-957. https://doi.org/10.1007/s13197-0110425-x.

Nadeem, M., Anjum, F.M., Murtaza, M.A. and Mueenud-din, G. (2012). Development, characterization, and optimization of protein level in date bars using response surface methodology. The Scientific World Journal, 2012, $518702 . \quad$ https:// doi.org/10.1100/2012/518702.

National Germplasm Resources Laboratory (2009). GRIN-Global Plant Germplasm. Retrieved from National Germplasm Resources Laboratory, Agricultural Research Service, USDA website: https://www.ars.usda.gov/northeast-area/beltsvillemd-barc/beltsville-agricultural-research-center/ national-germplasm-resources-laboratory/

Nimenibo-Uadia, R.L. (2017). Preliminary studies of Canavalia ensiformis (Jackbean) DC. Seeds: proximate analysis and phytochemical screening. Science World Journal, 12, 59-62.

Norajit, K., Gu, B.-J., and Ryu, G.-H. (2011). Effects of the addition of hemp powder on the physicochemical properties and energy bar qualities of extruded rice. Food Chemistry, 129(4), 1919-1925. https:// doi.org/10.1016/j.foodchem.2011.06.002

Okoye, J. and Eke-Ejiofor, J. (2018). Nutrient composition, lipid profile and sensory properties of cereal bar made from locally available cereals and nuts. International Journal of Biotechnology and Food Science, 6(1), 1-8.

Silva, E.P.D., Siqueira, H.H., Damiani, C. and Vilas Boas, E.V.D.B. (2016). Physicochemical and 
sensory characteristics of snack bars added jerivá flour (Syagrus romanzoffiana). Journal of Food Science and Technology, 36(3), 421-425. https:// doi.org/10.1590/1678-457X.08115

Sridhar, K.R. and Seena, S. (2006). Nutritional and antinutritional significance of four unconventional legumes of the genus Canavalia - A comparative study. Food Chemistry, 99(2), 267-288. https:// doi.org/10.1016/j.foodchem.2005.07.049

Tepal, J.A., Castellanos, R., Larios, A. and Tejada, I. (1994). Detoxification of Jack beans (Canavalia ensiformis): Extrusion and canavanine elimination. Journal of the Science of Food and Agriculture, 66 (3), 373-379. https://doi.org/10.1002/ jsfa. 2740660315

Unuofin, J.O., Otunola, G.A. and Afolayan, A.J. (2017). Essential oil composition, nutrient and anti-nutrient analysis of Vernonia mespilifolia less. Research Journal of Botany, 12(2), 38-45. https:// doi.org/10.3923/rjb.2017.38.45.

Vong, W.C., Hua, X.Y. and Liu, S.-Q. (2018). Solid state fermentation with Rhizopus oligosporus and Yarrowia lipolytica improved nutritional and flavour properties of Okara. LWT, 90, 316-322. https:// doi.org/10.1016/j.lwt.2017.12.050

Wan Mohamad Din, W.N.I., Mohd Zin, Z., Abdullah, M.A.A. and Zainol, M.K. (2020). The effects of different pre-treatments on the physicochemical composition and sensory acceptability of 'Kacang Koro' energy bar. Food Research, 4(5), 1162-1171. https://doi.org/10.26656/fr.2017.4(4).042

White, J.W.Jr., Riethof, M.L., Subers, M.H. and Kushnir, I. (1962). Composition of American Honeys. Washington, DC., USA: Agricultural Research Service, USDA,

Wilson, L.A. (1995). Soy Foods. In Erickson, D.R. (Ed.). Practical Handbook of Soybean Processing and Utilization, p. 428-459. USA: Academic Press and AOCS Press. https://doi.org/10.1016/B978-0-935315 $-63-9.50026-7$

Xiao, C.W. (2011). Functional soy products. In Sareela, M. (Ed.) Functional Foods. $2^{\text {nd }}$ ed., p. 534-556. USA: Woodhead Publishing Limited. https:// doi.org/10.1533/9780857092557.3.534

Zainol, M.K., Tan, R.C., Mohd Zin, Z., Ahmad, A. and Danish-Daniel, M. (2020). Effectiveness of Toothpony (Gazza minuta) protein hydrolysate on reducing oil uptake upon deep-frying. Food Research, 4(3), 805 - 813. https://doi.org/10.26656/ fr.2017.4(3).392

Zhu, D., and Labuza, T.P. (2010). Effect of cysteine on lowering protein aggregation and subsequent hardening of whey protein isolate (WPI) protein bars in wpi/buffer model systems. Journal of Agricultural and Food Chemistry, 58(13), 7970-7979. https:// doi.org/10.1021/jf100743z 